\title{
Efficacy of insecticidal seed treatment against pests of wheat
}

\author{
S.D. PATIL*, A.P. PADHYE AND S. KATARE ${ }^{1}$ \\ Agricultural Research Station, NIPHAD (M.S.) INDIA \\ ${ }^{1}$ Indian Institute of Wheat and Barley Research, KARNAL (HARYANA) INDIA
}

\section{ARITCLE INFO}

Received : 03.06 .2016

Revised : 02.08 .2016

Accepted : 16.08 .2016

\section{KEY WORDS :}

Wheat, Triticum aestivum, Rhopalosiphum padi (L),

Thiamethoxam, Clothianidin, Imidacloprid
*Corresponding author:

\begin{abstract}
Field experiments were conducted during Rabi 2012-13 to 2014-15 at Agricultural Research Station, Niphad, Maharashtra, India to determine the efficacy of promising insecticides used for seed treatment for the management of wheat pests. The insecticides were Thiamethoxam 30 FS @ 0.50, 0.75 and 1.00ml $/ \mathrm{kg}$ seed, Clothianidin 50 WDG @ $0.50,1.00$ and $1.50 \mathrm{~g} / \mathrm{kg}$ seed, Imidacloprid $48 \mathrm{FS} @ 0.50$ and $1.00 \mathrm{ml} / \mathrm{kg}$ seed, Chlorantraniliprole 18.5 SC @ 0.50 and $1.00 \mathrm{ml} / \mathrm{kg}$ seed. Thiamethoxam 30 FS @ 1.0 $\mathrm{ml} / \mathrm{kg}$ seed, Clothianidin 50 WDG @ 0.50, 1.00 and $1.50 \mathrm{~g} / \mathrm{kg}$ seed and Imidacloprid 48 FS @ 0.50 and $1.00 \mathrm{ml} / \mathrm{kg}$ seed were found the most effective as they didn't show the aphid population as an untreated control recorded the maximum of 44.08 number of aphids/shoot/plant. The seed treated with thiamethoxam 30FS, clothianidin 50 WDG and Imidacloprid 48FS were found effective for the control of jassids and shoot fly. Thiamethoxam 30FS @ 1.00ml/kg seed recorded significantly highest yield of 55.26q/ ha and also the highest (53.45g) 1000 grain weight. Lowest yield was observed from untreated control $(34.12 \mathrm{q} / \mathrm{ha})$. The additional yield and income over control was highest (21.14q/ha and Rs. 44480/ha) in thiamethoxam 30FS @ $1.00 \mathrm{ml} / \mathrm{kg}$ seed. The monetory returns, net profit and benefit cost ratio were maximum in treatment with thiamethoxam 30FS @ 1.00ml/kg seed (Rs.114607/-, 81377/ha and 3.44).
\end{abstract}

How to view point the article : Patil, S.D., Padhye, A.P. and Katare, S. (2016). Efficacy of insecticidal seed treatment against pests of wheat. Internat. J. Plant Protec., 9(2): 372-380, DOI : 10.15740/HAS/IJPP/9.2/372-380. 